\title{
Social Representations of Gynecologic Cancer Screening Assessment a Qualitative research on Ecuadorian women
}

\author{
Representações Sociais acerca dos Programas de Tamisação de Câncer \\ Ginecológico em mulheres Equatorianas: Um Estudo Qualitativo desde a \\ Percepção das Usuárias dos Serviços de Atenção Primária de Saúde \\ Representaciones Sociales acerca de los Programas de Tamizaje de Cáncer \\ Ginecológico en mujeres Ecuatorianas: Un Estudio Cualitativo desde la \\ Percepción de las Usuarias de Servicios de Atención Primaria de Salud \\ Yolanda Godoy ${ }^{1}$, Clara Godoy ${ }^{2}$, Juan Reyes ${ }^{3}$
}

${ }^{1}$ Pontifical Catholic University of Ecuador (Pontificia Universidad Católica del Ecuador PUCE), Department of Medicine. Postgraduate in Obstetrics and Gynecology, Quito, Ecuador

${ }^{2,3}$ INTEGRA Counseling Group Center for Integral Development, Tumbaco. Latin American Corporation for Holistic Thinking (Corporación Latinoamericana de Pensamiento Integral CLAPEI), Quito, Ecuador

\section{ABSTRACT}

The purpose of this work was to explore: knowledge, attitudes, and beliefs regarding gynecologic cancer screening on Ecuadorian women users of primary care facilities, to identify the social representations that users of health services make about these programs and their influence on the decision to undergo a screening.

An exploratory and qualitative research design was held using focus groups and in-depth interviews for data collection. A narrative content analysis of the results was conducted. Women's knowledge on gynecological cancer screening was confusing. Most frequent misconceptions related to the pap smear were: the belief that it could be useful for detecting pregnancy, ovarian cysts or infections. Most of the participants stated that the pap smear procedure is a traumatic and painful experience. Regarding to mammography women said it was used for sick woman and this procedure by itself may cause cancer.

\section{DESCRIPTORS}

Gynecological Cancer Screening; Pap Smear; Mammography, Qualitative Research. 


\section{INTRODUCTION}

In Ecuador during 2012, 664 women died from cervical cancer, and the estimated incidence for 2013 was 15.8 cases per 100,000 citizens; however, important differences were noted between the country's various provinces ${ }^{(1)}$. Cervical cancer detected during stage IA has a five-year survival rate of nearly $99 \%$, while the survival rate of women with stage IV cancer is between 15 and 20\%, according to the International Federation of Gynecology (Federación Internacional de Ginecología - FIGO) ${ }^{(2,3)}$.

In our country, a large number of advanced cases continue to be reported, and mortality rates continue to be quite high. The percentage of advanced cases is due in part to poor coverage of impoverished populations living in rural areas and also to the limited effectiveness of messages regarding early detection programs ${ }^{(4)}$.

Regarding breast cancer, in Ecuador, 30 of 100,000 people are diagnosed each year, approximately half of which are in an advanced stage, which decreases the likelihood of successful treatment and survival ${ }^{(3)}$. We would do well to heed the observations made by Pino and Alban in their 2006 study: 'It appears there is a group of women who never in their lives avail themselves of health services and, even if they do, their deaths cannot be avoided' (5).

Starting with the concept of social representations, the present study explored the values, knowledge, and experiences of users of the cervical and breast cancer early detection programs (Gynecological DOC), with the goal of identifying the meanings that women derived from messages provided by health professionals and other sources of information.

Social representations include elements such as opinions, beliefs, and perceptions and constitute a particular type of understanding through which people acquire physical and social realities. This form of knowledge acquisition is integral to a group or to daily social interactions and presents a mode of interpreting reality. 'Social representation is a particular type of knowledge: an organized body of understandings and one of the mental activities that allows individuals to make sense of physical and social realities integral to a group or a daily social interaction, liberating the powers of imagination' ${ }^{(6)}$.

According to Moscovici, social representations emerge or appear in circumstances of crisis or conflict in response to the need to classify and comprehend highly complex events. Fundamentally, the triggers of this emergence are the dissemination of information, focusing on the individual and collective subject, and the pressure of the implications of the socially defined object ${ }^{(7)}$. These conditions were identified by the research team as key to initiating the study process that coincided with massive national campaigns for breast cancer prevention.

Social representations allow people to familiarize that which initially appears as strange, resulting in the disappearance of the sense of threat that accompanies the unknown ${ }^{(8)}$. For many women, in 2008, the campaign 'Away with the Bra and Touch Yourself (Fuera Brazieres Tócate)' made breast cancer visible in a direct manner, which allowed the topic to be included in casual conversation, via sharing of fears and experiences. This fact was seen as an opportunity for the research team.

This research was based on the theory proposed by Gregory Bateson, which presents a view of the world as a network of relationships, connections, patterns, and context that allow a more complete understanding of the complex problems that individual disciplines, such as the sciences, attempt to address. Communication is the basic element of interpersonal relationships that allows us to put ourselves in another's place; it allows the ability to comprehend the feelings and thoughts of another without passing judgment and without necessarily putting ourselves on their side by simply finding links that allow us to connect to them from our particular circumstances ${ }^{(9,10)}$.

This research is a part of the work that the authors have performed in primary healthcare services over the past 16 years. All fieldwork personnel are associated with projects that promote the empowerment of women by creating spaces for gathering and reflection, which facilitates the understanding of the various scenarios in which the fieldwork was performed.

\section{POPULATIONS AND AREAS STUDIED}

This work was conducted between February and September 2009 and was developed in three phases; the first phase was undertaken in urban neighborhoods of the capital; the second phase was conducted in rural areas of the capital and a rural area in the city of Sangolquí; and finally, the third phase was conducted on a rural population in Guayas Province. Nine focus groups were conducted along with four in-depth interviews. The participants included 81 women between 18 and 65 years of age who were users of primary healthcare services in different urban and rural neighborhoods of the Metropolitan District of Quito and in two rural communities, one in Pichincha Province and the other in Guayas Province.

The focus groups were held in three middle-income urban neighborhoods in the capital, one low-income neighborhood in the capital, one rural neighborhood in the capital with a particularly high percentage of indigenous residents, two rural neighborhoods of the capital with most of their population involved in agricultural work, one rural neighborhood of the city closest to the capital that receives an internal and external migrant population, and finally a rural population in Guayaquil, the country's most populous city. The levels of education of the women participating were distributed as follows: illiterate, three (3\%); grade school, 17 (21\%); some high school, 34 (42\%); completed high school, 25 (31\%); and higher education, two (2\%).

The process of sorting the participants into groups began with identification of women who were influential in their setting, such as community mothers, midwives, neighborhood leaders, and mothers' club presidents. Once identified, these key women were presented with a summary of the topics to be discussed and were asked to collaborate in the formation of the groups. These contacts 
provided us with lists of users of primary healthcare services, including addresses and telephone numbers, and occasionally allowed us to use private facilities for focus groups. Each of the participants was contacted and invited to participate before being informed and providing their consent. The inclusion criteria were as follows: female, between 18 and 65 years of age, user of primary healthcare services, having undergone at least one Pap test, and willingness to participate in the study.

\section{METHODOLOGY}

A qualitative interpretive-explicative study was performed. The information was generated through focus groups and in-depth interviews with female primary healthcare users between 18 and 65 years of age. To promote participation, focus groups were held in private homes or community centers and were facilitated by women identified as neighborhood leaders or who were close to the fieldwork team. The exception was the focus group in the province of Guayas, which was held in the social area of the health clinic because the contact person used this address in the announcement. In each focus group, a female doctor familiar with education and qualitative research participated as a moderator, and a female sociologist observed.

A sampling was performed at the convenience of the researchers, using access and time as criteria. In selecting the sample, the women's profiles were defined to ensure that the information was rich, varied, and deep. The moderator worked without a defined script and was limited to facilitating discussion on whatever topics arose spontaneously. In very few cases was it necessary to insert content that had not been covered. At the end of each focus group, the first triangulation was performed with the participants. The fieldwork succeeded in bringing together the participants by approaching the communication process as one of empathy and respect between human beings.

In total, nine focus groups and four in-depth interviews were conducted. The interview participants consisted of women identified as key informants among the users of primary healthcare services (two midwives and two community leaders). Focus group data and interviews were stored as both voice files and digital files. Once transcribed, the recordings were complemented by the observer's notes. The data were triangulated for later narrative analysis and content interpretation, according to the initial categories of analysis and those that emerged. The data were segmented manually.

\section{RESULTS}

A total of 81 women from various socio-economic levels participated in the focus groups and in-depth interviews. Regarding the women's levels of education, $73 \%$ of the participants had partially complete or incomplete education, $3 \%$ were illiterate, and $2 \%$ had higher education.

The categories of analysis for the study were 1) the perception of DOC gynecologic programs, 2) social representations of DOC gynecologic procedures, 3) sources of information on cervical and breast cancers, and 4) factors determining the performance of procedures.

This study revealed that women in all groups confirmed awareness of the DOC gynecologic programs and valued them as important for health; however, with more in-depth discussion, we observed that this information was formed on an individual basis, with little relation to biomedical discourse. "When you have an infection, you should have a Papanicolaou performed, I believe it also helps see if you have any inflammation in your ovaries” M., 27 years old.

A significant number of women stated that, for them, the primary source of information about Pap smear programs was the use of primary healthcare services during their first pregnancy or after their first child. This demonstrates the lack of promotion of these programs, which are only discovered when women seek prenatal care or family-planning services. This is a worrisome finding because incidence and mortality rates increase with age; the majority of annual deaths in Latin America are documented to be between 35 and 54 years of age.

Many of the participants believe that a Pap smears should not be performed on women who have never been pregnant, as it can alter their fertility. "..if the girl is young and has not yet been pregnant, they shouldn't do it, it can make her sterile..., sometimes they scrape and can harm her" A., 63 years old.

The determining factors in choosing a health service were wait time, warmth of personnel, and confidence in exams. Many women choose private care because the wait times are shorter. It is worth noting that some women are willing to tolerate a certain degree of mistreatment if the professional is recognized as successful.

In this study, we observed that women's attitudes towards Pap smears are closely related to their experience in healthcare services. When this has been negative, it can cause these women to discontinue screenings, not seek out their test results, and even to cancel follow-up appointments. Participants reported fear, pain, and embarrassment as the most frequent elements associated with Pap smears. "It's scary, it hurts, and it's suspicious putting yourself there with your legs open, I wish there were another way" Y., 37 years old.

For some women, male professionals provided more "delicate" care. "Often male doctors are more sensitive than females, they're friendlier, they treat you better” S., 31 years old.

Regarding breast self-exams, the majority of participants regard them as a preventative massage that should be performed as often as possible. "...the breast massage, if possible, should be done every day" B., 19 years old.

A mammogram, according to the women, is an exam performed on cancer patients and, if performed on a healthy person, can trigger the disease.

In various focus groups, the participating women cited messages from movie and television stars about breast self-exams and mammograms as a source of information on cancer detection programs. Another information source was advertising attached to undergarments. "More than 
anything, I think it's because of the actresses that have had something in their breasts, and they've created this campaign against breast cancer and also when they sell bras, they advise you that they're part of an anti-cancer campaign" P., 27 years old.

Tables 1,2, and 3 summarize the main findings in relation to the categories studied.

Table 1 - Social representations regarding breast self-exams and mammograms

\begin{tabular}{|c|c|}
\hline $\begin{array}{l}\text { SOCIAL } \\
\text { REPRESENTATIONS } \\
\text { REGARDING BREAST } \\
\text { SELF-EXAMS }\end{array}$ & $\begin{array}{l}\text { - Procedure most identified for breast } \\
\text { - Mancer detection. } \\
\text { in that it acts as a "massage" that } \\
\text { "dissolves" possible growths via } \\
\text { friction. } \\
\text { - The slogan "Touch Yourself" was } \\
\text { very effective, evoking the curative } \\
\text { power of touch. }\end{array}$ \\
\hline $\begin{array}{l}\text { SOCIAL } \\
\text { REPRESENTATIONS } \\
\text { REGARDING } \\
\text { MAMMOGRAMS }\end{array}$ & $\begin{array}{l}\text { - Considered dangerous, associated } \\
\text { with procedures for patients already } \\
\text { diagnosed with cancer. } \\
\text { - The majority of participants believe } \\
\text { that it can cause cancer and "a } \\
\text { healthy woman should not have it } \\
\text { performed". }\end{array}$ \\
\hline
\end{tabular}

Table 2 - Source of information about DOC gynecologic programs

SOURCES OF INFORMATION FOR THE AWARENESS OF DOC
GYNECOLOGIC PROGRAMS

\begin{tabular}{ll}
\hline \multirow{2}{*}{ CERVIX } & $\begin{array}{l}\text { Prenatal care, female friends, and mass media (HPV } \\
\text { vaccine commercials). }\end{array}$ \\
\hline & $\begin{array}{l}\text { Self-exam: “Touch Yourself" campaign, } \\
\text { media figures, and publicity associated with }\end{array}$ \\
Bndergarments.
\end{tabular}

Table 3

\begin{tabular}{ll}
\hline $\begin{array}{l}\text { FACTORS DETERMINING THE PERFORMANCE OF DOC } \\
\text { PROCEDURS }\end{array}$ \\
\hline CERVIX & $\begin{array}{l}\text { Quality of relationship with healthcare professional. } \\
\text { Accessibility: hours, distance, and wait time. }\end{array}$ \\
\hline \multirow{2}{*}{ BREAST } & $\begin{array}{l}\text { Self-exam: publicity is essential, but it is unclear how to } \\
\text { accomplish this. }\end{array}$ \\
& $\begin{array}{l}\text { Clinical breast exam: lack of knowledge, performed when } \\
\text { changes are noted. }\end{array}$ \\
\cline { 2 - 3 } & Mammograms: lack of knowledge, fear, and accessibility. \\
\hline
\end{tabular}

\section{DISCUSSION}

Social representations emerge when people discuss issues of mutual interest or when certain topics are presented by mass media as relevant ${ }^{(7,8)}$. This research was performed in 2009, months after the start of the "Away with the Bra and Touch Yourself (Fuera Brazieres Tócate)" campaign, which had a national impact.

Assessing the social representations of the DOC gynecologic programs allowed us to approximate the ways in which women process both the information they receive from service providers and mass media and that which they derive from personal stories of experiences with healthcare services ${ }^{(11,12)}$. This combination of message content plus experience serves as a reference point for shaping an attitude on a concrete procedure such as a Pap smear or a mammogram ${ }^{(13)}$.

The Pap smear procedure is surrounded with an interesting symbolism: going to the doctor's office; removing one's clothing, sometimes in front of one or more strangers; climbing onto the exam table; assuming the gynecological position; being observed; and finally being manipulated with instruments, which all provoke a sensation of great vulnerability and recapitulate experiences of mistreatment and discrimination.

The information most acknowledged and appreciated by women is that which is derived from nonmedical sources, as it is perceived as more familiar and less threatening $(14,15)$. The conclusion is that women have unmet needs in areas such as access to primary healthcare services, appropriate information on the value of exams, prolonged wait times for results, and other areas related to the behavior of healthcare personnel ${ }^{(16)}$.

For women, the breast self-exam is the most known and practiced procedure ${ }^{(17)}$. The "Touch Yourself" campaign was met with wide acceptance because it invokes belief in the power of touch, friction, and contact.

The information that women receive from various sources, including their family environment, healthcare services, and their personal experience, is processed through their imagination ${ }^{(18)}$. Therefore, for messages from gynecological cancer early-detection programs to be clear, they should consider the socio-cultural contexts of the recipients. Likewise, healthcare professionals should also bear these in mind to ensure the success of these programs ${ }^{(15,17)}$.

\section{CONFlicts OF INTEREST}

The authors declare that they have no commercial, personal, or institutional relationships that could be categorized as conflicts of interest.

\section{Authors' Contributions}

The authors declare that they have contributed equally to the study and to the creation of this article.

\section{RESUMO}

O propósito desta investigação foi explorar os conhecimentos e crenças respeito aos programas de detecção do câncer ginecológico, entre usuárias de centros de atenção primaria de saúde, para identificar as representações sociais que as usuárias dos centros de saúde elaboram acerca de estes programas e dos diferentes procedimentos que compreendem.

O desenho da investigação foi exploratório e qualitativo, mediante grupos focais e entrevistas a profundidade, com a respectiva análise narrativa e interpretativa do conteúdo. Encontrou-se conhecimento confuso acerca dos programas de tamisação de câncer ginecológico e dificuldades associadas à realização dos procedimentos.

Os significados mais frequentes acerca dos programas foram o uso da citologia cérvico-vaginal para detectar gravidez, quistos ováricos ou 
infecções. A maioria das participantes associava este procedimento com una experiência dolorosa e traumática. Respeito ao autoexame de mamas, o identificaram como uma massagem preventiva-terapêutica e à mamografia, como perigosa porque poderia desenvolver câncer.

\section{DESCRITORES}

Detecção Oportuna do Câncer Ginecológico; Citologia Cérvico-Vaginal; Mamografia, Representações Social, Investigação Qualitativa

\section{RESUMEN}

El propósito de esta investigación fue explorar los conocimientos, actitudes y creencias respecto a los programas de detección del cáncer ginecológico entre usuarias de centros de atención primaria de salud para identificar las representaciones sociales que las usuarias de los servicios de salud elaboran acerca de estos programas y de los diferentes procedimientos que comprenden.

El diseño de la investigación fue exploratorio y cualitativo, mediante grupos focales y entrevistas a profundidad, con el respectivo análisis narrativo e interpretativo del contenido. Se encontró conocimiento confuso acerca de los programas de tamizaje de cáncer ginecológico y dificultades asociadas a la realización de los procedimientos.

Los significados más frecuentes acerca de los programas fueron: el uso de la citología cérvico-vaginal para detectar embarazo, quistes ováricos o infecciones. La mayoría de los participantes asociaba este procedimiento con una experiencia dolorosa y traumática. Respecto al autoexamen de mamas, lo calificaron como un masaje preventivo-terapéutico y a la mamografía como peligrosa porque podría desarrollar cáncer.

\section{DESCRIPTORES}

Detección Oportuna del Cáncer Ginecológico; Citología Cérvico-Vaginal; Mamografía, Representaciones Sociales, Investigación Cualitativa

\section{REFERENCES}

1. Sociedad de lucha contra el cáncer. Registro Nacional de Tumores. SOLCA Núcleo Quito: 2010

2. Organización Panamericana de la Salud. Análisis de la situación del cáncer cérvicouterino en America Latina y el Caribe. Washington, D.C. OPS: 2004.

3. Pino, M. Albán, M. Análisis de la situación del cáncer de cérvix uterino en el Ecuador, 2006 REV ESP PATOL 2008; 41, 1: 41-47

4. Moscovici, Serge. El psicoanálisis, su imagen y su público. Buenos Aires: Huemul 1979

5. Mora, M. La teoría de las representaciones sociales de Serge Moscovici. Athenea Digital. Revista de pensamiento e investigación social, [S.I.], nov. 2002. ISSN 1578-8946. Disponible en: <http://atheneadigital.net/article/view/55>. [Citado 2015 Mayo 16] doi: http:// dx.doi.org/10.5565/rev/athenead/v1n2.55.

6. Farr Robert M. Las Representaciones Sociales en: Serge Moscovici. Psicología Social II. Barcelona Paidós 1986

7. Bateson G. Pasos hacia una ecología de la mente: colección de ensayos en antropología, psiquiatría, evolución y epistemología. Ballantine Books. 1972

8. Bateson G. Espíritu y Naturaleza. Editorial Amorrortu 1993

9. Oprea Gabriela M, Majmudar Bhagirath. The Pap Test : To err is Human. In: Roberts C. P, Broomfield D. P. Avoiding Common Obstetrics and Gynecology Errors. First Edition. Philadelphia: Lippincott Williams \& Wilkins; 2010. p. 256-259.

10. Alcaraz M., Lluch A., Miranda J., Pereiro I., Salas M.D.. Estudio de la no participación en el programa de prevención de cáncer de mama en la ciudad de Valencia. Gac Sanit [revista en la Internet]. 2002 Jun [citado 2016 Abr 05] ; 16(3): 230-235. Disponible en: http://scielo.isciii.es/scielo.php?script=sci_arttext\&pid=S0213-91112002000300006\&lng=es.

11. Usha Saraiya. Natural History of Cervical Cancer. In: Workshop Manual. Manual on Gynecological Oncology AICOG 2013. First Edition. New Delhi: Jaypee Brothers Medical Publishers (P) Ltd; 2013. p. 41-44.

12. Robles, Sylvia C., \& Galanis, Eleni. (2002). El cáncer de mama en América Latina y el Caribe. Rev Panam Salud Publica [revista en la Internet]. 2002 Ago, [Citado 2015 Mayo 16]; 12( 2 ): 141-143. Disponible en: http://www.scielosp.org/scielo.php? script=sci_ arttext\&pid=S1020-49892002000800016\&lng=en. http://dx.doi.org/10.1590/S1020-49892002000800016.

13. Cabeza Elena, Catalán Gustavo, Avellà Antoni, Llobera Joan, Pons Onofre. Conocimientos, creencias y actitudes de la población femenina de Mallorca respecto al cáncer. Rev. Esp. Salud Pública [revista en la Internet]. 1999 Jul [citado 2016 Abr 05]; 73(4): 485-495. Disponible en: http://scielo.isciii.es/scielo.php?script=sci_arttext\&pid=S1135-57271999000400006\&lng=es.

14. Domenighetti G, D'Avanzano B, Egger M, Berrino, F, Perneger T, Mosconi P, Zwahlen M. Women's perception of the benefits of mammography screening: population-based survey in four countries. Int J Epidemiol [revista en la Internet]. 2003 [citado 2016 Abr 05]; 32(5):816-821. Disponible en: http://ije.oxfordjournals.org/content/32/5/816.full.pdf+html

15. Ford S, Schofield T, Hope T. What are the ingredients for a successful evidence-based patient choice consultation?: A quality study. Soc Sci Med 2003; 56:589-602.

16. Masuet Cristina, Séculi Elisa, Brugulat Pilar, Tresserras Ricard. La práctica de la mamografía preventiva en Cataluña: Un paso adelante. Gac Sanit [revista en la Internet]. 2004 Ago [citado 2015 Mayo 16]; 18(4): 321-325. Disponible en: http://scielo.isciii.es/scielo. php?script=sci_arttext\&pid=S0213-91112004000600010\&lng=es.

17. Rebollo Palencia MR, Berlanga González MA, Casado Alonso Y, González Cuadrado MD, Ibáñez Pérez F, Aguirrezabala Jaca JR et al. Conocimientos y actitudes relacionados con la prevención del cáncer en la población atendida en un centro de salud. Aten Primaria 1996; 18: 417-24. Disponible en: http://www.elsevier.es/es-revista-atencion-primaria-27-articulo-conocimientos-actitudes-relacionados-con-prevencion-14393

18. Richa Saxena. Bedside Obstetrics \& Gynecology. Second Edition. New Delhi: Jaypee Brothers Medical Publishers; 2014. p. 853-855 
ACKNOWLEDGEMENTS

This study was funded by the Pontifical Catholic University of Ecuador (PONTIFICIA UNIVERSIDAD CATÓLICA DEL ECUADOR - PUCE). The authors would like to express their gratitude to the women who generously agreed to participate in the study. 